\title{
Tributary Alluvial Fan-Responses to Base-Level Fall by Axial Fluvial Incision: A Case in the Guadalquivir Valley (Córdoba, Spain)
}

\author{
M.A. Núñez Granados and J.M. Recio Espejo \\ Ecology Department (Physical environment and Geomorphology), Rabanales Campus, University of Cordoba, 14071 \\ Cordoba, Spain
}

\begin{abstract}
The geomorphological, sedimentological and pedological analysis of a group of 11 alluvial fans located in the northern flank of the Guadalquivir Valley has shown that their genesis and evolution were controlled by base-level fall caused by axial fluvial incision of the Guadalquivir River during the Quaternary.

The morphometric and morphological features of the study fans (i.e.: elongated plan-view, straight and concave longitudinal profiles, shallow incised channels in proximal sectors and shallow deposits) suggest that fan accommodation was predominantly progradational and the fluvial incision of the Guadalquivir River was therefore, insufficient to trigger distal erosion of the fans.

The absence of mature red soils provides evidence of fan activity during the Pleistocene, while young soils on the fan surfaces suggest that the fan dynamics became non-functional during the Early Holocene. The absence of Neolithic/Chalcolitic artefacts in the fan sediments supports this idea.
\end{abstract}

Keywords: Alluvial fan, base-level, Mediterranean, quaternary, red soils, southern Spain.

\section{INTRODUCTION}

General works have dealt with the role played by baselevel changes in controlling the development of many alluvial fans [1-4].

Tectonically-induced uplifts/subsidence [5] or climatically-induced rises/falls at lake and sea level $[6,7]$ might cause base-level changes. Indirectly, tectonic and climatic change might produce fluvial incision in axial rivers and cause base-level falls of its tributary fans [8].

Base-level falls typically produce distal incisions by trenches. Incisions might progress up to mountain fronts causing through-fan dissection of alluvial fans. Incised fans have deep and steep channels (that may cut bedrock), older surfaces that are only located in their proximal sector, and younger ones inset within fan trenches [6].

Fans might become inactive by the coupling of the ancient fan channel with axial fluvial systems [9] or by the capture of interfan streams to fanhead channels [1].

In other cases, if base-level falls are insufficient to generate incisions, fans develop by progradation $[6,10,11]$. These fans may be recognized by their elongated plan-view morphology [12], shallow fanhead trenches, and older surfaces buried by younger deposits [6].

During non-erosive and aggradational phases, pedological processes might occur on fans surfaces [13].

*Address correspondence to this author at the Ecology Department (Physical environment and Geomorphology), Rabanales Campus, University of Cordoba, 14071 Cordoba, Spain; Tel: +34 9572185 97;

Fax: +34 9572185 97; E-mail: man_largo@hotmail.es
Pleistocene soils with decarbonated and rubefacted horizons have been described on fan surfaces [14-16], while Early Holocene paleosoils with organic and hydromorphic features have been studied by other authors $[9,17]$.

This paper analyzes the morphological, sedimentological and pedological features of 11 alluvial fans located in the Guadalquivir Valley, focusing on fan development as a possible response to the overall base-level fall ocurring in the study area by axial incision during the Quaternary.

\section{STUDY AREA}

The study fans are located within the Guadalquivir alpine basin, in the central sector of the basin's northern Sierra Morena mountain front (Fig. 1). These mountains belong to the Hercynian system and are composed of Precambrian and Paleozoic rocks including vulcanite, limestone and slate. Depression materials are predominantly tectonicallyundeformed Tortonian marls $[18,19]$.

The Guadalquivir is the main river of the fluvial network of the region. An overall base-level fall controlled regional drainage during the Quaternary. Nine fluvial terrace levels have been described in both flanks of the Guadalquivir Valley [20]. They are organized chronostratigraphically [21, 22] from the Lower Pleistocene (higher terrace levels) to the Upper Pleistocene. The highest (and oldest) deposits are located at 320 meters above sea level $(230 \mathrm{~m}$ above the current river course) (Fig. 2).

The alluvial fans are located in a outcrop of marls that is bordered to the North by the Sierra Morena mountain front and to the South by a fluvial terrace of the Guadalquivir River located at 120 m.a.s.1. ( $+30 \mathrm{~m}$ above the current 

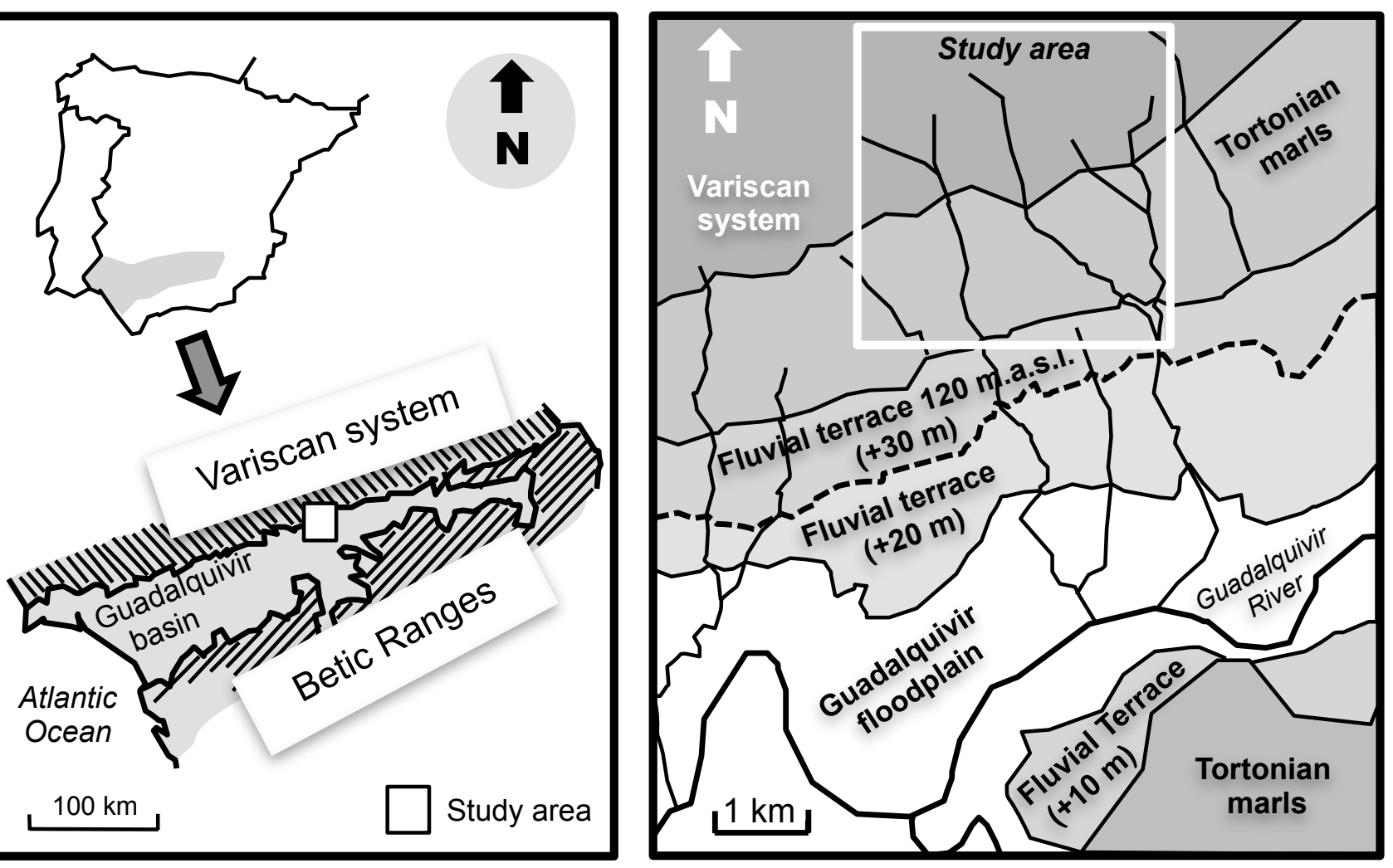

Fig. (1). Location of the study area within the Guadalquivir geological basin.

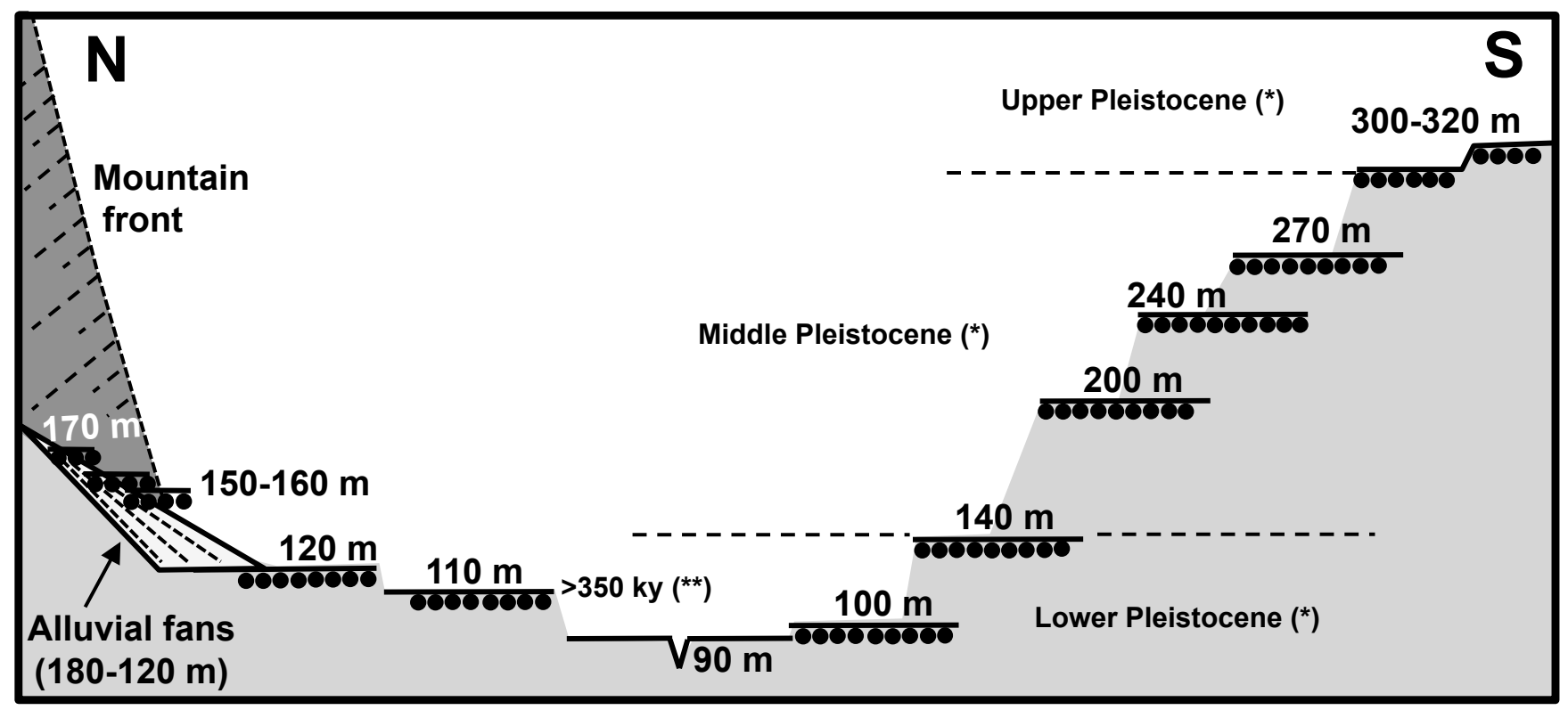

Fig. (2). Morphostratigraphic sketch of alluvial fans and fluvial terraces in the Guadalquivir Valley (central sector). Chronology data are based on Baena and Díaz del Olmo (1994) (*) and Recio et al. (2008) (**).

course of the river) (Fig. 3). The drainage basins of the fans are carved in vulcanite, limestone and slate outcrops of the mountains

The drainage network of the study area comprises a group of northern tributaries of the Guadalquivir River (Fig. 3). In the headwater sector, corresponding to the Sierra Morena mountains, the watercourses are parallel, short, steep and straight. In the lower sector, where streams reach the Guadalquivir basin, the alluvial fans are dissected and the drainage pattern becomes dendritic.

The current climate of the study area is typically Mediterranean, with an average rainfall of approximately 550 $\mathrm{mm}$ and an average annual temperature of $18{ }^{\circ} \mathrm{C}$. The annual P-ETP balance shows a clear deficit value of 


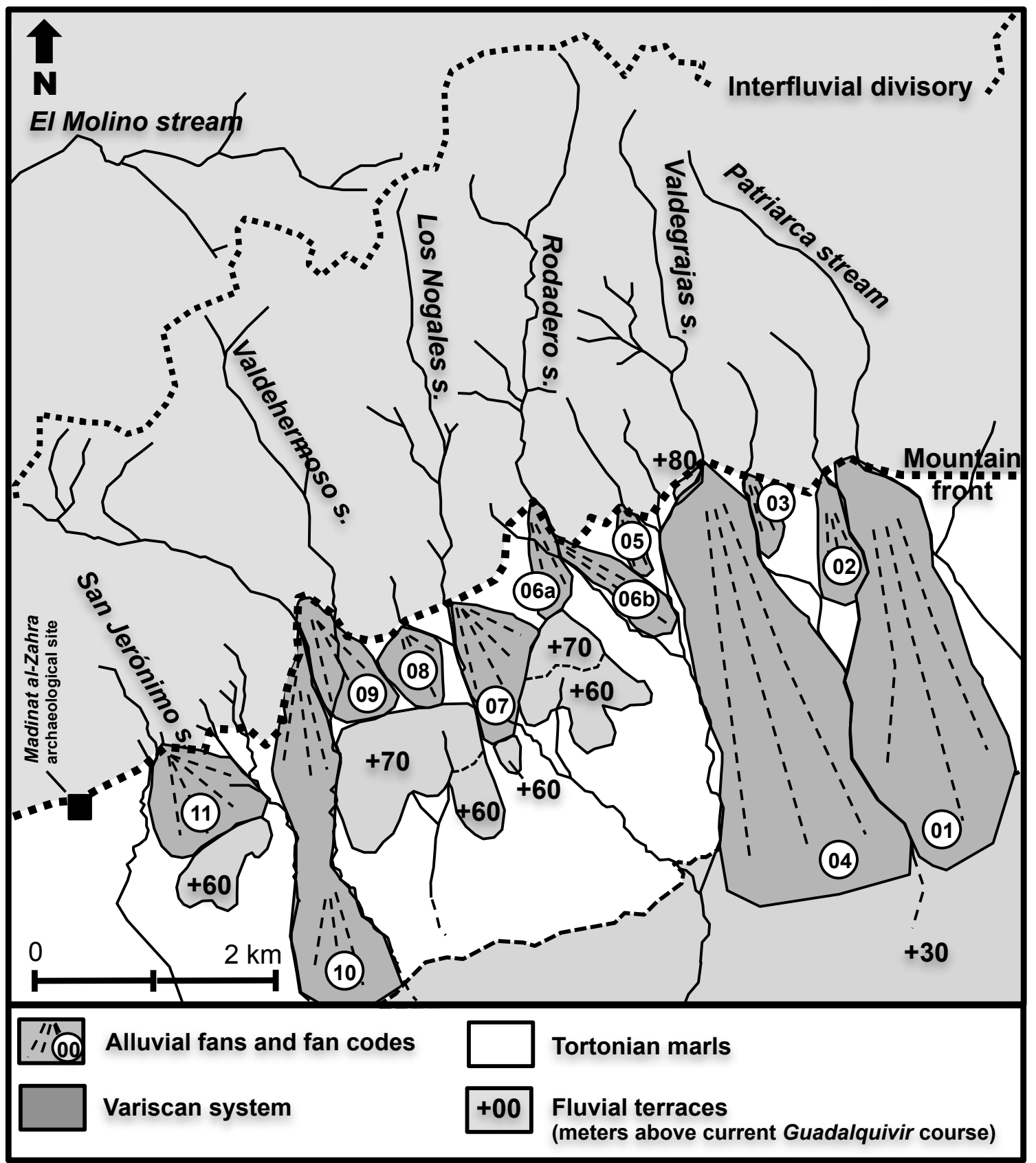

Fig. (3). Map of study fans. Note location of Quaternary terrace deposits.

$-196 \mathrm{~mm}$. Natural vegetation grows in the mountains while crops predominate in the valley. According to some authors [22, 23] Mediterranean conditions predominated in the region during the Pleistocene, although some climatic variations have been detected by pedological studies [24, 25].

\section{MATERIALS AND METHODS}

A morphologic and morphometric analysis of 11 discrete alluvial fans was performed. Geomorphologic mapping and topographic profiles were made using 1:10.000 maps, aerial photographs and 2-meters contour lines map DTM generated, with the support of field surveys.

The following morphometric parameters were used: Fan area (total planimetric area of each fan), Basin area (total planimetric area of each drainage basin), Length (axial length of each fan), Width (measure at middle of longitudinal axis), Elongation (width/length ratio for each fan) and Gradient (average gradient of each fan).

In order to find correlations between some of these parameters, correlation coefficients were calculated using Spearman's rank method. Due to the small size of the sample $(\mathrm{N}=11)$, other more powerful statistical methods could not be used. This has made it impossible to calculate regression analysis.

Two fans were selected for sedimentological and pedological characterization. Three soil profiles corresponding to proximal, midfan and distal positions were studied for each characterization. Soil profiles were identified following FAO [26] guidelines. Soil color was defined in dry conditions, using the Munsell scale [27]; soil $\mathrm{pH}$ was measured potentio- 
metrically in a 1:1 soil-water suspension, in a Schott CG818 instrument using the Guitián and Carballas method [28] and carbonate content was determined using a Bernard calcimeter, in accordance with the Duchaufour [29] method. In order to evaluate the vertical distribution of organic matter, three samples were taken along each profile. The organic matter content of the samples was determined using the method described by Sims and Haby [30].

\section{RESULTS}

\subsection{Morphometric Parameters}

The study fans are generally small in size, with fan areas ranging from 0.06 to $2.08 \mathrm{~km}^{2}$ (Table 1). Fans 01 and 04 are the largest fans (1.40 and $2.08 \mathrm{~km}^{2}$, respectively). The fan apices are located at altitudes of between 160 and 185 m.a.s.l., while the fan toes end between 165 and 120 m.a.s.l.

All the fans have a similar plan-view morphology, with high elongation values (Table 1). Elongation values range from 0.22 to 0.77 , with an average of 0.44 . The fans have values lower than 0.5 (length more than twice the width) with the exception of fans 05, 07, 08 and 11 .

The fan gradients (\%) are steep, with values between 1.8 and 5.6 and an average of 3.14. Except fans 01 and 02, all the fans have slopes steeper than 2.0. Gradient is positively correlated with Elongation (Table 2).

No statistically significant correlations were detected for the Elongation-Fan area, Basin area-Gradient or ElongationBasin area pairs. The basin area shows a positive correlation with Fan area.

\subsection{Morphological Features}

An analysis of the longitudinal profiles shows that shorter fans (fans 02, 03, 05, 08, 09, 11) have straight profiles, while longer fans have concave profiles. These concave profiles are complex and comprising several sedimentation phases. A topographical comparative analysis between profile irregularities has shown no evidence of common phases in the sedimentation of the fans (Fig. 4).

Table 1. Morphometric parameters of alluvial fans.

\begin{tabular}{|c|c|c|c|c|c|c|c|c|}
\hline $\begin{array}{l}\text { Fan } \\
\text { Code }\end{array}$ & $\begin{array}{c}\text { Fan } \\
\text { Name }\end{array}$ & $\begin{array}{l}\text { Height } \\
\text { Interval }\end{array}$ & $\begin{array}{c}\text { Fan Area } \\
\left(\mathbf{K m}^{2}\right)\end{array}$ & $\begin{array}{c}\text { Basin Area } \\
\left(\mathbf{K m}^{2}\right)\end{array}$ & $\begin{array}{l}\text { Length } \\
\text { (m) }\end{array}$ & $\begin{array}{l}\text { Width } \\
\text { (m) }\end{array}$ & $\begin{array}{c}\text { Elongation } \\
\text { Width/Length }\end{array}$ & $\begin{array}{c}\text { Gradient } \\
\text { (\%) }\end{array}$ \\
\hline 01 & Patriarca-I & $165-120$ & 1.400 & 0.795 & 2452 & 873 & 0.36 & 1.8 \\
\hline 02 & Patriarca-II & $160-145$ & 0.152 & 0.324 & 797 & 242 & 0.30 & 1.9 \\
\hline 03 & Turruñuelos & $165-145$ & 0.093 & 0.261 & 530 & 118 & 0.22 & 3.8 \\
\hline 04 & Valdegrajas & $175-120$ & 2.084 & 1.320 & 2300 & 862 & 0.37 & 2.4 \\
\hline 06 & Rodadero & $180-140$ & 0.375 & 2.072 & 1317 & 385 & 0.29 & 3.0 \\
\hline 07 & Nogales & $175-155$ & 0.373 & 1.592 & 922 & 587 & 0.64 & 2.2 \\
\hline 08 & Torrecilla & $175-160$ & 0.192 & 0.175 & 482 & 346 & 0.71 & 3.1 \\
\hline 09 & Valdehermoso & $185-165$ & 0.232 & 1.569 & 920 & 384 & 0.41 & 2.2 \\
\hline
\end{tabular}

Table 2. Spearman's rank correlations between different morphometric variable pairs of the alluvial fans $\left(r_{s}=S\right.$ Spearman coefficient). Correlations are significant at $\mathbf{p}<0.05$.

\begin{tabular}{|c|c|c|c|c|}
\hline Variable Pairs & $\mathbf{N}$ & $\mathbf{r}_{\mathrm{s}}$ & $t(d f-2)$ & p-Level \\
\hline Fan area-Basin area & 11 & $0.636^{*}$ & 2.475 & 0.035 \\
\hline Fan area-Gradient & 11 & 0.046 & 0.137 & 0.894 \\
\hline Basin area-Elongation & 11 & 0.091 & 0.274 & 0.790 \\
\hline Length-Elongation & 11 & -0.437 & -1.459 & 0.179 \\
\hline Length-Gradient & 11 & -0.214 & -0.658 & 0.527 \\
\hline Width-Elongation & 11 & -0.055 & -0.164 & 0.873 \\
\hline Width-Gradient & 11 & 0.082 & 0.247 & 0.811 \\
\hline
\end{tabular}




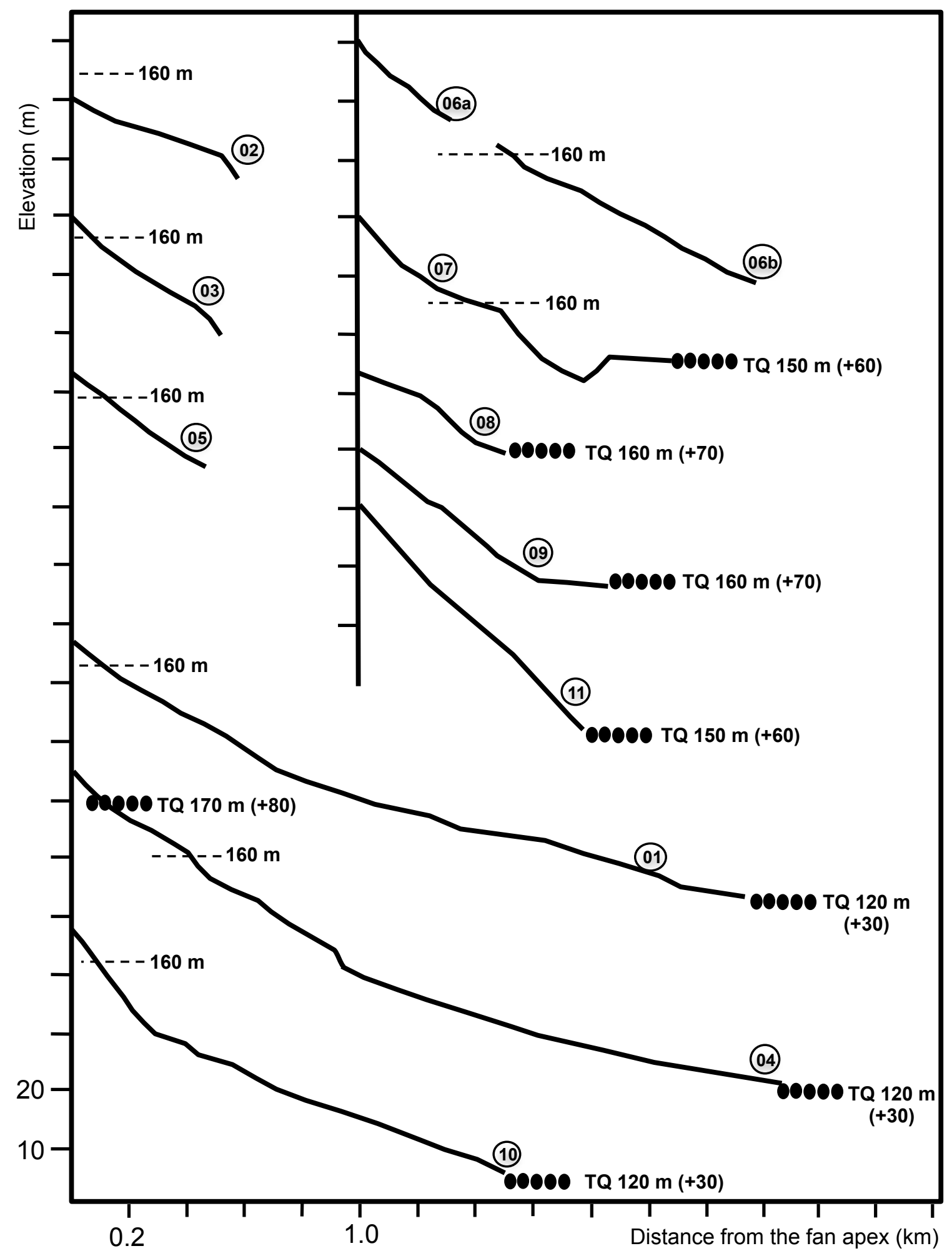

Fig. (4). Longitudinal profiles of study fans. Vertical exaggeration is 20. Elevation intervals are arbitrary.

The fluvial terrace levels located in the study area (Fig. 3) are comprised of discontinuous deposits $(+80,+70$ and +60 meters above the current course of the Guadalquivir River) and one continuous level $(+30 \mathrm{~m})$. Depending on the fan size and location, the fluvial terraces might reach one of these levels (except +80 level, which is located in the headfan of fan 04). The three longest fans lie on the lower level (+30 m) (fans 01, 04 and 10). Four fans are not related to any terrace level (fans 02, 03, 05 and 06). Fans 07 and 11 lie on the +60 level and fans 08 and 09 lie on the +70 level (Fig. 4).

The fans are non-functional, and currently have no active lobes fed by feeder channels. They are dissected by the current fluvial network in their proximal sectors (dissection 
in fans 07 and 09 occurs in their midfan sector) with a 2-3 meter incision affecting alluvial material and bedrock. The channels leave fan segments to take interfan paths and flow down to the Guadalquivir River. No gullies or other evidence of distal fan trenching were detected.

\subsection{Sedimentary Facies}

The sediments of the study area are mostly coarse and formed by vulcanite clasts coming from their basins, except fans 01 and 02 which have finer sediments and a lower proportion of clasts.

The sediments of the two largest fans (fans 01 and 04) were described in their proximal, middle and distal positions (Fig. 5). In both fans, debris-flow deposition dominates in proximal zones, while the middle and distal positions are characterized by fluvial processes (Fig. 6).

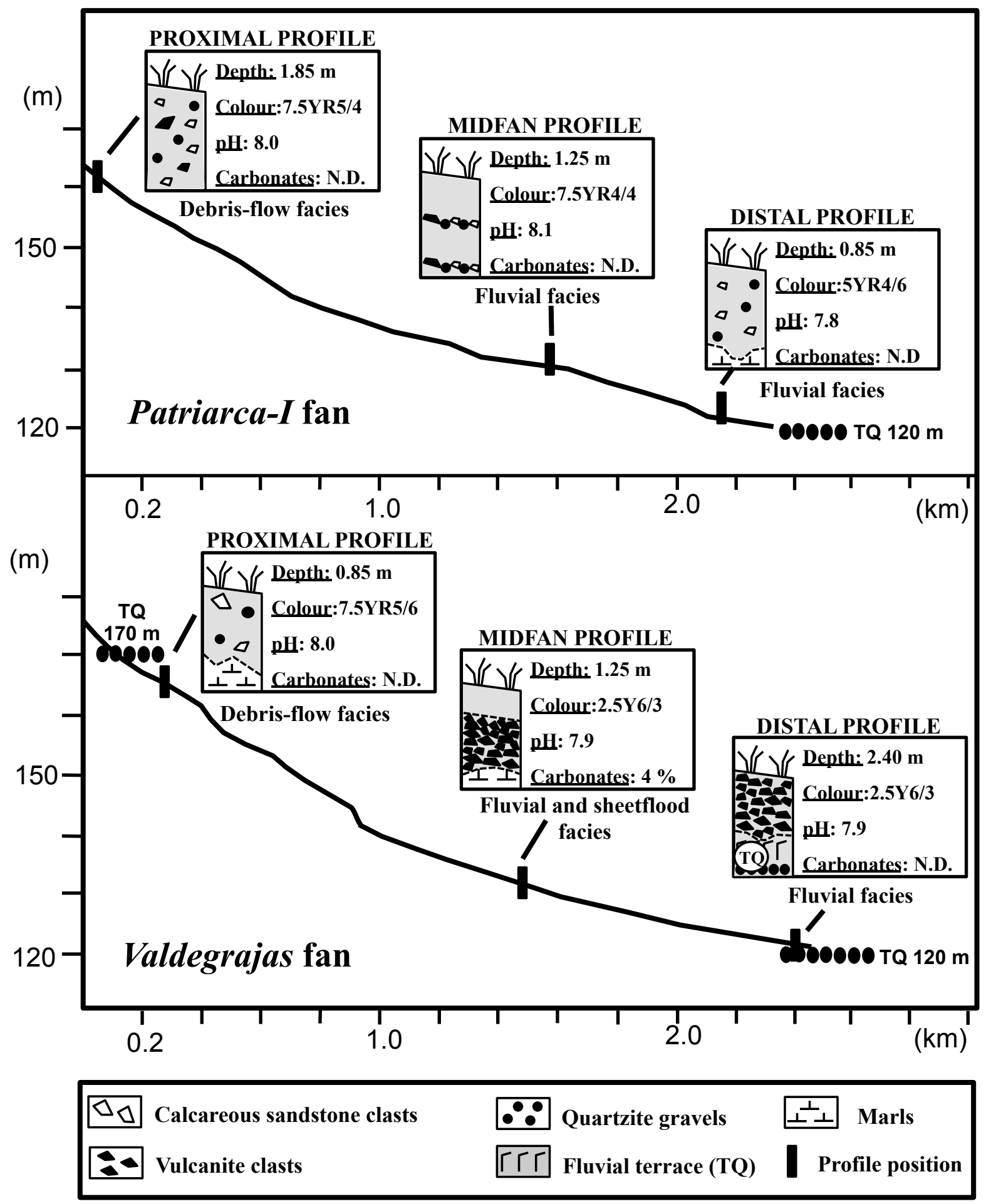

Fig. (5). Profiles of Patriarca-I (01) and Valdegrajas (04) fans. Vertical exaggeration is $\mathrm{x} 20$. Data correspond to samples located in alluvial deposits. Color is calculated in dry conditions. 

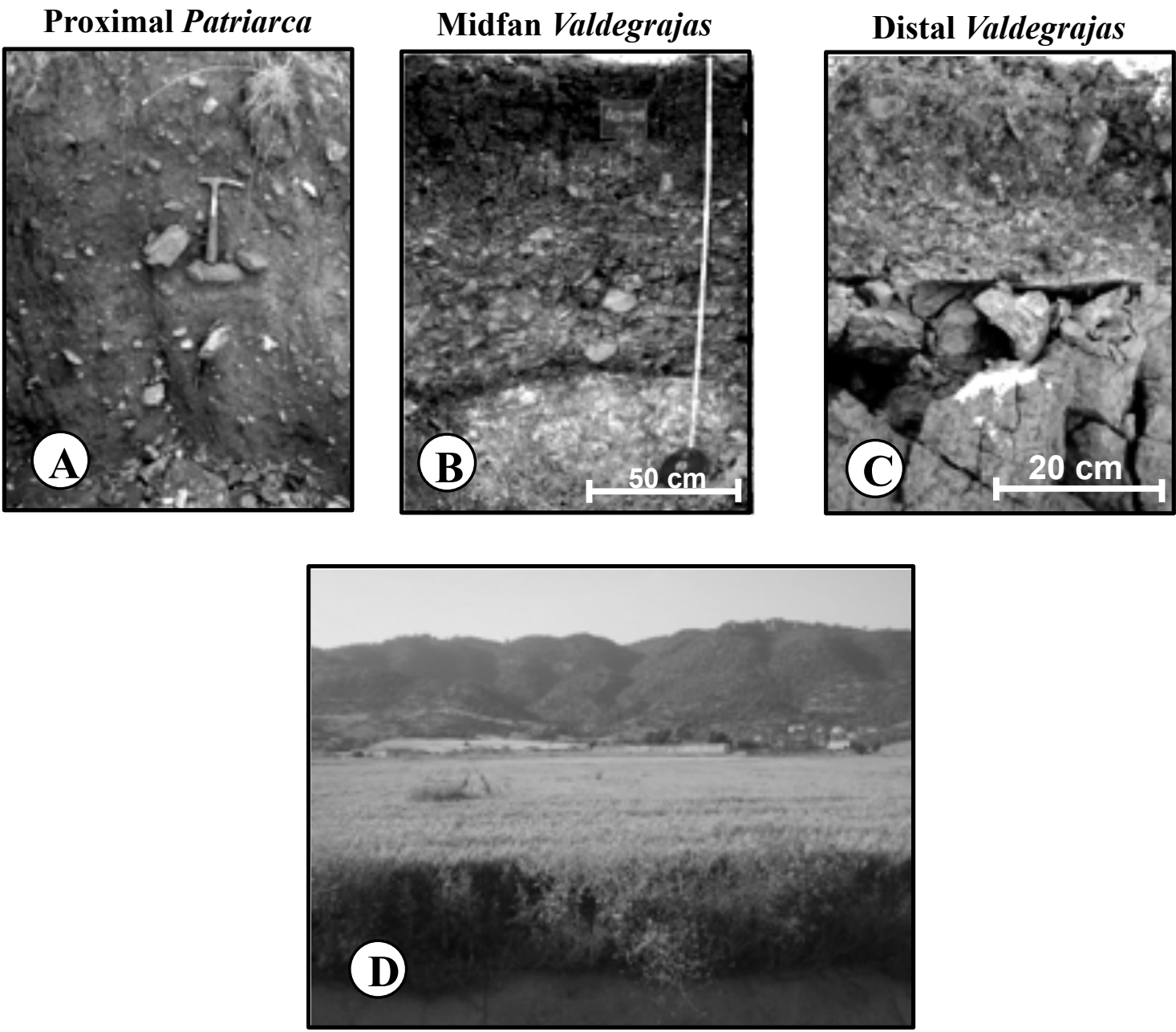

Fig. (6). Photographs of fan sediments: (A) Debris-flow facies in the proximal sector within the Patriarca fan. Hammer (25 $\mathrm{cm})$ for scale. (B) Sheetflood deposit overlying fluvial facies in the Valdegrajas midfan. Note the underlying Tortonian marls. (C) Detail of erosional contact affecting fluvial terrace level at 120 m.a.s.l. (D) General view of the Valdegrajas fan (04) and its drainage basin.

The alluvial deposits in the study profiles have depths between 0.85 and $1.25 \mathrm{~m}$, with overlying Tortonian marls by irregular contact. In its distal profile, the Valdegrajas fan is $2.40 \mathrm{~m}$ in depth and lies on terrace deposits at 120 m.a.s.1. $(+30 \mathrm{~m})$.

The sedimentological features of both fans are related to the lithological differences between the drainage basins. The Valdegrajas fan sediments are coarse and composed of angular cobble-size clasts of vulcanite rocks. These sediments come from outcrops of the fan basin. Nevertheless, in some proximal positions, the sediments incorporate materials from fluvial terraces of $+80 \mathrm{~m}$.

The sediments of the Patriarca fan are predominantly fine, with a small amount of rounded quartzite and angular limestone clasts from the limestone and cemented quartzitic conglomerate located in its basin.

\subsection{Pedological Features}

A field description of the macromorphological features of the study profiles (located in the proximal, middle and distal positions of fans 01 and 04) (Figs. 5, 6) has detected no evidence of red Mediterranean soils of the Pleistocene [17,
22, 25]. Hence, no rubefiedargillic and carbonated B horizons or secondary carbonates and argilliccutans were identified in the profiles.

Only evidence of incipient and superficial pedogenesis was detected. Organic matter determination showed relatively high contents $(>2 \%)$, a homogeneous vertical distribution and higher contents in superficial samples (Table 3). $\mathrm{pH}$ values are high (between 7.8 and 8.1) and generally uniform along each profile with higher levels in upper positions.

Color is also homogeneous in each profile. Differences in color were detected between both fans, with yellowish brown colors predominating in the Valdegrajas fan, and strong brown colors in the Patriarca fan; differences which are probably related to the lithology of each drainage basin. Carbonates are absent in both fans, except in the middle profile of the Valdegrajas fan ( $4 \%$ of fine-grained calcite).

\section{DISCUSSION}

Following previous works $[6,12]$ we have provided morphologic and morphometric evidence of progradation: a) elongated plan-view morphologies (values lower than $0.5)$; b) straight and concave longitudinal profiles; c) shallow 
Table 3. Vertical distribution of organic matter content, $\mathrm{pH}$ and color in study profiles. The depth (in $\mathrm{cm}$ ) of the sample point is shown in parentheses.

\begin{tabular}{|c|c|c|c|c|c|c|c|}
\hline \multicolumn{4}{|c|}{ Patriarca fan (01) } & \multicolumn{4}{|c|}{ Valdegrajas fan (04) } \\
\hline Profile & Organic Matter (\%) & $\mathbf{p H}$ & Color & Profile & Organic Matter (\%) & pH & Color \\
\hline \multirow{3}{*}{$\begin{array}{l}\text { Proximal } \\
(25-75-100)\end{array}$} & 4.3 & 8.0 & $7.5 \mathrm{YR} 4 / 4$ & \multirow{3}{*}{$\begin{array}{l}\text { Proximal } \\
(20-40-60)\end{array}$} & 2.7 & 7.6 & $7.5 \mathrm{YR} 4 / 6$ \\
\hline & 4.0 & 8.0 & 7.5YR5/4 & & 2.2 & 8.0 & $7.5 \mathrm{YR} 5 / 6$ \\
\hline & 4.2 & 8.1 & $7.5 Y R 5 / 4$ & & 1.2 & 8.1 & $7.5 \mathrm{YR} 5 / 6$ \\
\hline \multirow{3}{*}{$\begin{array}{l}\text { Midfan } \\
(25-75-100)\end{array}$} & 3.6 & 8.0 & $7.5 \mathrm{YR} 4 / 4$ & \multirow{3}{*}{$\begin{array}{l}\text { Midfan } \\
(20-40-80)\end{array}$} & 3.4 & 7.7 & $2.5 \mathrm{YR} 6 / 2$ \\
\hline & 3.5 & 8.1 & $7.5 \mathrm{YR} 4 / 4$ & & 2.7 & 7.9 & $2.5 \mathrm{YR} 6 / 3$ \\
\hline & 3.4 & 7.8 & $7.5 \mathrm{YR} 5 / 4$ & & 2.5 & 7.9 & $2.5 \mathrm{YR} 6 / 3$ \\
\hline \multirow{3}{*}{$\begin{array}{l}\text { Distal } \\
(25-75-100)\end{array}$} & 0.27 & 7.7 & $7.5 \mathrm{YR} 4 / 4$ & \multirow{3}{*}{$\begin{array}{l}\text { Distal } \\
(20-100-150)\end{array}$} & 2.6 & 7.8 & 2.5 YR6/3 \\
\hline & 0.27 & 8.0 & 5YR4/6 & & 2.5 & 7.9 & 2.5 YR6/3 \\
\hline & 0.00 & 8.0 & 7.5YR4/6 & & 2.4 & 7.9 & 2.5 YR6/3 \\
\hline
\end{tabular}

$(<3 \mathrm{~m})$ incised channels in proximal sectors; and d) shallow deposits (lower than $2.5 \mathrm{~m}$ ).

The progradation dynamics of the study fans appear to be caused by base-level fall related to Quaternary fluvial incision of the Guadalquivir River. According to Harvey [6], this incision should have been slow and therefore noneffective in triggering distal incision. The absence of gullies and other evidence of the erosion of distal sector of fans support this idea.

The topographical analysis of the longitudinal profiles of the fans shows no evidence of common depositional stages (Figs. 3, 4), thus indicating that fan accommodation was controlled by the depositional capacity of each fan. This suggests that during fan evolution, base-level fall was generally continuous, without long stability phases.

Certain morphological and sedimentological features of the fans such as steep longitudinal gradients (especially in the proximal sectors), and debris-flow facies in fanhead positions might be closely related to the coarse nature of the sediments, which are mostly formed by vulcanite clasts [14]. Thus, fans with sediments finer than vulcanite clasts, (fans 01 and 02) have gentler gradients.

Although winnow processes have been proposed to explain concave longitudinal profiles in fans with clastic sediments in proximal positions [14], coarse materials in the distal position of the study fans with concave morphologies suggest that they were formed by the redistribution of sediments due to progradational dynamics.

The chronostratigraphical data obtained for the fluvial terraces of the study area suggest that the alluvial fans began to develop in the Middle Pleistocene because their apex altitudes are higher than the Middle/Upper Pleistocene limit (140 m.a.s.1.) (Fig. 2) as detected by Baena and Díaz del Olmo [20].

All the fans are currently inactive and disconnected to their feeder channels. Pedological evidence points to the ocurrence of an incisional stage during the Early Holocene. Thus, no mature red soils formed during the Pleistocene [17, 22] were detected, and only young soils with superficial processes appear in the study fans.
Furthermore, no evidences of later Early Holocene fan activity was found. In spite of the widespread occupational of the region during the Neolithic and Chalcolithic periods, no archaeological artefacts were found inside the fan sediments.

\section{CONCLUSION}

Quaternary fluvial incision of the Guadalquivir River caused a regional base-level fall in the river basin. The different fluvial terrace levels provide evidence of this incisional process.

From the Middle Pleistocene this base-level fall produced a set of alluvial fans in the mountain front located at the northern limit of the Guadalquivir Valley. Fluvial incision was insufficent to trigger distal erosion of the fans and determined fan accommodations by progradation.

Due to the absence of long stability phases during the Guadalquivir incision, common topographical levels are not present in the longitudinal profiles of the fans. The sedimentary capacity of each fan controlled their accommodation to the valley morphology. Thus, only the largest fans reached the lower position of the study area (continuous terraces deposits at 30 meters above the current river course).

The Pleistocene activity of the fans prevented the formation of mature red soils on old surfaces. During the Early Holocene, before the Neolithic/Chalcolithic periods, the fans state became inactive due to incision processes. Feeder channels were captured by interfan streams producing incised channels of 2 to 4 meters in depth. Young and thin soils then developed on the fan surfaces, but were strongly affected by anthropic activities from the Roman period onwards [31].

\section{CONFLICT OF INTEREST}

The authors confirm that this article content has no conflict of interest.

\section{ACKNOWLEDGEMENTS}

The authors are grateful to Prof. Ricardo Reques for providing advice on the statistical treatment of data and thank David Gómez for his help with the cartography. 


\section{REFERENCES}

[1] Bull WB. The alluvial fan environment. Progn Phys Geog 1977; 1: $222-70$.

[2] Harvey AM. Factors influencing Quaternary alluvial fan development in Southeast Spain. In: Rachocki AH, Church M, Eds. Alluvial Fans: A Field Approach. Wiley: Chichester 1990; pp. 24769.

[3] Gómez Villar A. Abanicos aluviales: aportación teórica a sus aspectos más significativos. Cuaternario y Geomorfología 1996; 10(3-4): 77-124.

[4] Gutiérrez Elorza M. Geomorfología Madrid, Spain: Pearson 2008.

[5] Calvache M, Viseras C, Fernandez J. Controls on alluvial fan development-evidence from fan morphometry and sedimentology; Sierra Nevada, SE Spain. Geomorphology 1997; 21: 69-84.

[6] Harvey AM. The role of base-level change in the dissection of alluvial fans: case studies from Southeast Spain and Nevada. Geomorphology 2002; 45: 67-87.

[7] Harvey AM. Differential effects of base-level, tectonic setting and climatic change on Quaternary alluvial fans in the northern Great Basin, Nevada, USA. In: Harvey AM, Mather AE, Stokes M, Eds. Alluvial Fans: Geomorphology, Sedimentology, Dynamics. London, UK: Geological Society, Special Publications (251) 2005; pp. 117-31.

[8] Al-Farraj A, Harvey AM. Desert pavement characteristics on wadi terrace and alluvial fan surfaces: Wadi Al-Bih, U.A.E. and Oman. Geomorphology 2000; 35: 279-97.

[9] Silva PG, Bardají T, Calmel-Avila M, Goy JL, Zazo C. Transition from alluvial to fluvial systems in the Guadalentín Depression (SE Spain) during the Holocene: Lorca Fan versus Guadalentín River. Geomorphology 2008; 100: 140-53.

[10] Bowman D. The declining but non-rejuvenating base-level. The Lisan Lake, the Dead sea, Israel. Earth Surf Process Landforms 1988; 13: 239-49.

[11] Frostick LE, Reid I. Climatic versus tectonic controls of fan sequences: lessons from the Dead Sea, Israel. J Geologic Soc London 1989; 146: 527-38.

[12] Viseras C, Calvache M, Soria JM, Fernández J. Differential features of alluvial fans controlled by tectonic or eustatic accommodation space. Examples from the Betic Cordillera, Spain. Geomorphology 2003; 50: 181-202.

[13] Birckeland PW. Soils and Geomorphology. UK: Oxford University Press 1984.

[14] Harvey AM, Silva PG, Mather AE, Goy JL, Stokes M, Zazo C. The impact of Quaternary sea-level and climatic change on coastal alluvial fans in the Cabo de Gata ranges, Southeast Spain. Geomorphology 1999; 28: 1-22.

[15] Günster N, Eck P, Skowronek A, Zöller L. Late Pleistocene loess and their paleosols in the Granada Basin, Southern Spain. Quat Int 2001; 76/77: 241-5.
Pope R, Wilkinson K. Reconciling the roles of climate and tectonics in Late Quaternary fan development on the Spartan piedmont, Greece. In: Harvey AM, Mather AE, Stokes M, Eds. Alluvial Fans: Geomorphology, Sedimentology, Dynamics. London, UK: Geological Society, Special Publications 2005; pp. 133-52.

[17] Núñez MA, Recio JM. Holocene pedoenvironmental situations in the Eastern Sierra Morenaregión (Andújar, Spain). Quat Int 2002; 93-94: 191-4.

[18] Ramírez F, Castelló R, Armengot J. Mapa Geológico de España escala 1:50000, $2^{\mathrm{a}}$ Serie (MAGNA), Hoja de Córdoba (923) Madrid, Spain: IGME. Servicio de Publicaciones $\mathrm{M}^{\mathrm{o}}$ Industria 1973.

[19] Leyva F. Mapa Geológico de España escala 1:50000, 2a Serie (MAGNA), Hoja de Espejo (944). Madrid, Spain: IGME. Servicio de Publicaciones del $\mathrm{M}^{\mathrm{o}}$ Industria 1976.

[20] Baena R, Díaz del Olmo F. Cuaternario aluvial de la depresión del Guadalquivir: episodios geomorfológicos y cronología paleomagnética. Geogaceta 1994; 15: 102-4.

[21] Clemente L, Paneque G. Propiedades, génesis y clasificación de suelos de terrazas del Valle del Guadalquivir. Anales de Edafología y Agrobiología 1974; 3-4: 215-258 and 295-314.

[22] Torrent J. Genesis and properties of the soils of the Mediterranean regions. Universitá Degli Studi Di Napoli Federico II Dipartamento di Scienze Chimico-Agrarie. Napoli, Italy 1995.

[23] Suc JP, Bertini A, Combourieu-Nebout N, et al. Structure of West Mediterranean vegetation and climate since 5.3 Ma. Acta Zoollogica Cracoviensia 1995; 38(1): 3-16.

[24] Delgado R, Aguilar J, Delgado G. Use of numerical estimator and multivariate analysis to characterize the genesis and pedogenesis evolution of Xeralfs from southern Spain. Catena 1994; 23: 309-25.

[25] Recio JM, Faust D, Núñez MA, Zielhofer C. Accumulation of secondary carbonate evidence by ascending capillary in Mediterranean argillic horizons (Córdoba, Andalusia, Spain). Soil Sci 2008; 173: 350-8.

[26] F.A.O. Guía para la descripción de perfiles de suelos. F.A.O.: Roma, Italy 1984.

[27] Munsell Color. Munsell soil color charts. Maryland, USA: Koll Morgen Instruments 1976

[28] Guitián F, Carballas T. Técnicas de análisis de suelos. Santiago, Spain: Editorial Pico-Sacro 1976

[29] Duchaufour Ph. Edafología. Barcelona, Spain: Editorial TorayMasson 1975.

[30] Sims JR, Haby VA. Simplified colorimetric determination of soil organic matter. Soil Sci 1971; 62: 137-41.

[31] Ventura A. El abastecimiento de agua a la Córdoba romana II Servicio de Publicaciones de la Universidad de Córdoba. Colección Monografías n 251: Córdoba, Spain 1996. 